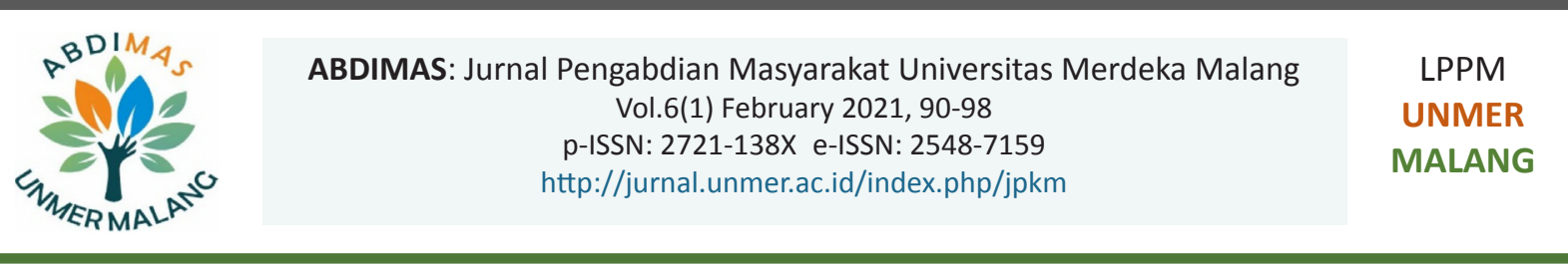

\title{
Pelatihan Pengembangan Produk Kreatif dari Rotan pada IKM di Jombang dengan Pelibatan Masyarakat
}

\author{
Gunawan', Guguh Sujatmiko², Dudi Anandya³ \\ ${ }^{1}$ Fakultas Teknik, ${ }^{2}$ Fakultas Industri Kreatif, ${ }^{3}$ Fakultas Bisnis dan Ekonomika, Universitas Surabaya \\ Jl. Raya Kalirungkut, Surabaya, 60293, Indonesia
}

\begin{abstract}
ARTICLE INFO
Received: 2020-09-30

Revised: 2020-11-03

Accepted: 2021-01-17

Keywords:

Community development, Craft, Furniture, Rattan, Wood

\section{ABSTRACT}

In moving towards adapting to new habits during the COVID-19 pandemic, efforts to revive the economy from small and medium-sized enterprises (SMEs) are essential. UD. Delima Jaya, a small wood-furniture firm in Catak Gayam Village, Mojowarno, Jombang regency, targets the local-product development program. The SME empowerment intervention principle consists of 3 elements: Market Needs - Supply chain networks - Internal Capabilities. This principle is applied to an activity program by supporting partners in exploring market needs, selecting new products to be developed, establishing partnerships that form supply chains, involving community members as production partners, enhancing production capabilities, and supporting marketing products personally and creatively. This method has been applied by obtaining market demand for wood and rattan combination products, getting partners for marketing, and bringing partners with production expertise. The training was held for 1 week in July 2020 at PPPUD partner locations by involving local women, with two instructors from outside Jombang. The training results show the fast mastery of skills among the participants and the quality of products made. This program helps SMEs and the community to rise in economic activities.

(C) 2021 Published by University of Merdeka Malang.

This is an open access article distributed under the CC BY-SA 4.0 license

(https://creativecommons.org/licenses/by-sa/4.0/)

How to cite: Gunawan, G., Sujatmiko, G., \& Anandya, D. (2021). Pelatihan Pengembangan Produk Kreatif dari Rotan pada IKM di Jombang dengan Pelibatan Masyarakat. Abdimas: Jurnal Pengabdian Masyarakat Universitas Merdeka Malang, 6(1), 90-98. https://doi.org/10.26905/abdimas.v6i1.4852
\end{abstract}

\section{PENDAHULUAN}

Usaha pembuatan mebel kayu telah banyak menarik perhatian untuk dikaji, karena usaha tersebut berkembang dari industri rakyat, membentuk suatu klaster industri di daerah, dan menunjukkan kekhasan produk mebel sebagai wujud dari kearifan lokal. Industri mebel yang berkembang pada dasarnya (sejarahnya) berkembang dari pengrajin kayu, yang memanfaatkan bahan baku lokal di sekitar mereka dan menjangkau konsumen lokal pula. Selanjutnya bertumbuh menjadi Industri Kecil dan Menengah (IKM) dengan sejumlah pekerja. Kajian untuk meningkatkan daya saingnya dengan mengungkapkan faktor penyebabnya telah banyak dikaji. Misalkan, kajian tentang klaster industri mebel di Jepara telah membahas faktor kondisi, kondisi permintaan, industri pendukung, strategi perusahaan dan persaingan, 


\section{Pelatihan Pengembangan Produk Kreatif dari Rotan pada IKM di Jombang dengan Pelibatan Masyarakat}

Gunawan, Guguh Sujatmiko, Dudi Anandya

peran pemerintah, kesempatan, dan modal sosial (Handayani et al., 2012). Dengan keterbatasan ketersediaan bahan baku kayu khususnya kayu jati, naiknya harga kayu telah berdampak pada penurunan permintaan produk yang dialami para IKM (Handayani et al., 2016).

Klaster atau sentra industri mebel tidak hanya yang terkenal di Kabupaten Jepara (Nurrochmat et al., 2015) tapi juga di berbagai daerah lain seperti Klaten, Jawa Tengah (Nurlaela et al., 2014) dan Kuningan, Jawa Barat (Iskandar et al., 2018). Salah satunya ialah di Kabupaten Jombang di Jawa Timur merupakan salah satu daerah penghasil kayu dari Perum Perhutani Divisi Regional Jawa Timur. Kecamatan Mojowarno di Jombang ditetapkan sebagai sentra industri kecil dan menengah pengrajin kayu (mebel). Persaingan produk dengan sesama IKM baik di klaster yang sama atau antar klaster, dan juga dengan perusahaan skala besar menjadi tantangan yang dihadapi setiap IKM mebel. Salah satu solusi bisnis ialah inovasi produk untuk menghasilkan produk yang sesuai permintaan pasar, baru, dan kreatif.

Perkembangan suatu IKM sangat ditentukan dengan kemampuan kewirausahaan dari pemilik atau pengelola. Suatu studi pada UKM mebel di Jepara mendapatkan keterkaitan antara kemampuan wirausaha dan modal sosial dengan keunggulan bersaing (Muslikah et al., 2018). Keberhasilan IKM diukur dengan keberhasilannya dalam menjual produknya. Sebuah studi pada IKM mebel di Kuningan mengungkapkan bahwa kelemahan IKM dalam membuat produk mebel berorientasi pasar berkaitan dengan penurunan kinerja pemasarannya (Iskandar et al., 2018). Tulisan ini menampilkan bagaimana IKM mitra PPPUD (selanjutnya disebut IKM mitra) ini menjalankan orientasi pasar dan meningkatkan kemampuannya.

Dalam pendekatan bisnis, untuk produk baru dengan kandungan teknologi yang rendah, misalkan produk mebel kayu, inovasi produk baru perlu mengacu pada permintaan pasar daripada kebaruan produk itu sendiri. Didalam masa pandemi COVID-19 yang mulai terjadi di Indonesia sekitar Maret 2020, upaya pengembangan produk baru dari industri kecil yang mengaitkan dengan kondisi masyarakat menjadi hal yang menarik. Artikel ini bertujuan untuk memaparkan kegiatan Program Pengembangan Produk Unggulan Daerah (PPPUD) pada IKM mebel di desa Catak Gayam seperti disebutkan di atas. Secara khusus artikel akan berfokus pada serangkaian aktivitas upaya pengembangan produk baru kombinasi kayu dan rotan dengan menerapkan prinsip jejaring rantai pasok dan melibatkan masyarakat sekitar.

Pelaksana kegiatan PPPUD ini adalah tim dari Universitas Surabaya (Ubaya). Ubaya mempunyai dan melaksanakan rencana strategis pengabdian kepada masyarakat tahun 2016-2020, yang didalamnya menyatakan 7 fokus pemerintah daerah yaitu, Kabupaten Sidoarjo, Mojokerto, Jombang, Bojonegoro, Probolinggo, Pamekasan, dan Kota Surabaya. Didalam dokumen dinyatakan bahwa konsep pengabdian masyarakat berdasarkan klaster kawasan, dimana salah satunya ialah klaster kawasan agropolitan dan agroindustri. Didefinisikan bahwa klaster kawasan agropolitan dan agroindustri merupakan daerah dengan potensi utama berupa pertanian, perikanan darat, peternakan, dan merupakan daerah lumbung pangan baik di daerah maupun nasional. Program-program yang dapat dikembangkan meliputi pengembangan kuantitas dan kualitas produksi hasil-hasil pertanian, strategi pengembangan agroindustri masyarakat berbasis pada produk hasil pertanian dan peternakan menjadi produk olahan dan pemasarannya. Kecamatan Mojowarno di Kabupaten Jombang merupakan daerah yang dipilih di klaster kawasan tersebut. Menurut RPJMD Kabupaten Jombang 2013-2019, disebutkan bahwa Kabupaten Jombang 
ABDIMAS: Jurnal Pengabdian Masyarakat Universitas Merdeka Malang

Volume 6, No. 1, February 2021: 90-98

merupakan daerah penghasil kayu, khususnya kayu jati. Dengan adanya bahan baku lokal ini, sangat beralasan munculnya industri rakyat (industri kecil dan menengah) dalam pembuatan mebel.

\section{METODE}

Metode pelaksanaan yang diterapkan dikategorikan sebagai Metode Community Development dan Metode Edukatif.

\section{Metode Kegiatan}

Dalam metode community development ini, IKM mitra yaitu pengelola dan pekerja sebagai subjek dalam kegiatan. Metode edukatif diterapkan secara khusus untuk program pelatihan sebagai sarana proses transfer pengetahuan praktis untuk perbedayaan IKM beserta masyarakat yang terlibat.

Metode pelaksanaan dimodelkan dengan 3 aspek yaitu: (1) Menerapkan prinsip orientasi pasar untuk mendapatkan produk baru yang akan dikembangkan. Kompetensi yang dikembangkan dengan pelatihan harus sesuai dengan kebutuhan (peluang) pasar. Aspek ini diwujudkan ke dalam 2 aktivitas yaitu melakukan eksplorasi pasar dan menetapkan keterampilan pengembangan produk yang dipilih; (2) Membentuk jejaring rantai pasok desain-produksi-pemasaran. Jejaring rantai pasok yang dimaksud ialah membentuk relasi dengan pihak hilir yaitu yang mempu membeli produk IKM mitra, dan pihak hulu yaitu yang membantu peningkatan kemampuan dalam proses produksi. Demikian juga, membangun relasi masyarakat ditujukan dengan mendapatkan mitra dalam produksi; (3) Meningkatkan kemampuan teknologi internal. Peningkatan kemampuan dilakukan dengan pelatihan pengembangan produk dengan narasumber instruktur yang berpengalaman.

Masing-masing aspek dijalankan dengan 2 aktivitas sehingga didapatkan 6 langkah pelaksanaan kegiatan pelatihan untuk peningkatan kemampuan produksi mulai dari tahap eksplorasi kebutuhan pasar hingga memasarkan produk. Model dari metode pelaksanaan ditampilkan pada Gambar 1.

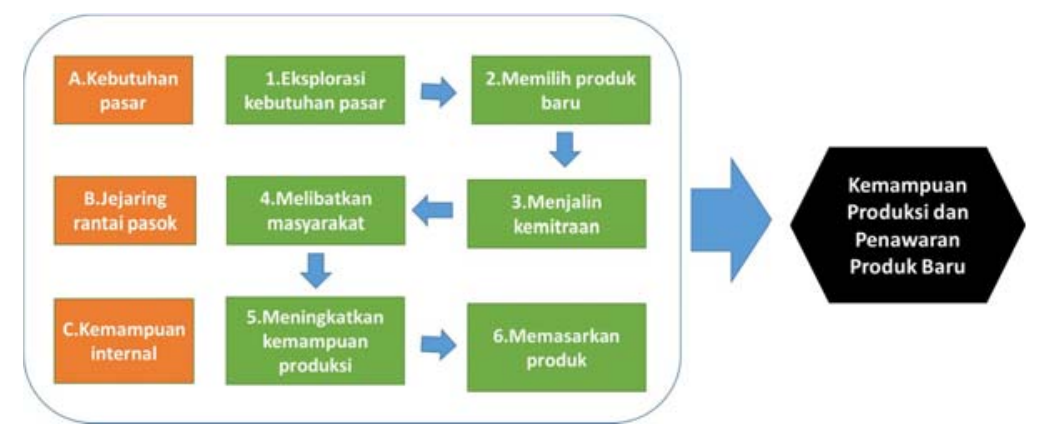

Gambar 1. Metode pelaksanaan

\section{Rancangan Evaluasi}

Pelaksanaan program pengabdian dalam bentuk pelatihan di IKM mitra dengan melibatkan masyarakat sekitar. Terdapat 3 kriteria yang menjadi tolak ukur dasar pencapaian dari kegiatan pelatihan. 
(1) Tolak ukur keberhasilan dari mitra UKM, adalah terlaksananya kegiatan yang berhasil menghadirkan instruktur eksternal yang kompeten, menghadirkan peserta dari masyarakat sekitar, menyediakan tempat pelatihan, dan meningkatnya skill pekerja; (2) Tolak ukur keberhasilan dari peserta, antara lain adalah peserta mampu mendapatkan keterampilan dan mempraktikkannya dalam membuat produk dari rotan; (3) Tolak ukur keberhasilan tim pelaksana, adalah terlaksananya kegiatan secara keseluruhan, kepuasan UKM mitra, kepuasan peserta, dan terlaksananya dokumentasi kegiatan dari vendor.

\section{HASIL DAN PEMBAHASAN}

\section{Aspek A: Kebutuhan Pasar}

\section{Aktivitas 1: Melakukan eksplorasi peluang pasar}

IKM mitra secara rutin tetap bisa menerima pesanan produk konvensional misalkan pintu, jendela, meja kursi, dan lemari. Desain produk tersebut juga berkembang dengan perubahan variasi-variasi kecil. Pelaksana PPPUD memberikan motivasi kepada IKM mitra tentang menangkap peluang pasar pada produk baru. Pelaksana PPPUD berperan dalam berdiskusi dan menampilkan contoh produk yang ada di pasar untuk memberikan gagasan (concept generation). Diskusi bersama IKM mitra mendapatkan beberapa potensi produk baru misalkan produk kayu untuk upaya produk ramah lingkungan (misalkan peralatan makan dan minum dari kayu), produk kombinasi kayu dan besi, dan produk kombinasi kayu dan rotan. IKM mitra diminta untuk eksplorasi lebih lanjut dengan melihat produk pesaing.

\section{Aktivitas 2: Memilih produk baru yang dikembangkan}

IKM mitra perlu memutuskan prioritas produk baru yang akan dikembangkan. Proses pemilihan konsep produk (concept selection) terhenti ketika Pandemi COVID-19 terjadi. Ketika kegiatan ekonomi mulai didorong lagi di masa pandemi, IKM mitra memilih produk kombinasi kayu rotan, dengan pertimbangan bahwa pembuatan atau penganyaman rotan bisa melibatkan masyarakat sekitar. Dengan demikian, dampak ekonomi pada masyarakat akan bisa terjadi. Yang dimaksudkan produk di sini, bukan satu produk tetapi kelompok produk kreatif yang diproduksi dengan bahan baku kayu dan rotan. Produk mebel dari rotan sebenarnya sudah mempunyai sejarang panjang di Indonesia. Di pasar internasional produk mebel rotan bisa mempunyai nilai tambah yang sangat tinggi untuk pembeli kelas dunia (Pratono, 2019). Produk baru yang dipilih IKM mitra bukan dalam pengertian produk inovasi yang baru di pasar, namun merupakan inovasi tambahan (incremental innovation). Hal ini sesuai dengan hasil kajian inovasi pada IKM mebel di Jawa Tengah bahwa para IKM cenderung melakukan incremental innovation dalam pembuatan produk baru (Kusumawardhani \& Mccarthy, 2013).

\section{Aspek B: Jejaring Rantai Pasok}

\section{Aktivitas 3: Menjalin kemitraan yang membentuk rantai pasok}

Upaya menjalin kemitraan terjadi bersamaan dengan identifikasi produk baru. Mitra bisnis yang dijalin oleh IKM mitra ialah sebuah usaha yang berfungsi dalam desain dan pemasaran. Usaha tersebut 
ABDIMAS: Jurnal Pengabdian Masyarakat Universitas Merdeka Malang

Volume 6, No. 1, February 2021: 90-98

yang berada di Kota Malang, sudah melaksanakan penjualan produk kayu rotan ke pasar luar negeri. Usaha tersebut juga melakukan desain produk, namun tidak melakukan produksi. Upaya menjalin kemitraan dilakukan dengan prinsip komplementer, dimana IKM mitra akan berperan sebagai salah satu mitra dalam produksi.

\section{Aktivitas 4: Melibatkan warga masyarakat sebagai mitra produksi}

IKM mitra mempunyai wawasan dan pengalaman dalam memberdayakan potensi masyarakat melalui upaya bersama meningkatkan ekonomi. Dalam program pengembangan produk kombinasi kayu rotan ini, masyarakat yang berpartisipasi ialah kelompok ibu-ibu di sekitar. Pemilik dan pengelola dari IKM mitra, UD. Delima Jaya, ialah seorang perempuan yang meneruskan usaha ini dari generasi sebelumnya. Pemilik IKM mitra telah menjalin komunikasi kepada kelompok ibu-ibu setempat. Komunikasi berhasil meyakinkan kelompok ibu-ibu, dan mereka bersedia mengikuti pelatihan menganyam rotan. Para ibu diberikan peluang bahwa setelah pelatihan bisa menggunakan keterampilan untuk usaha sendiri, atau sebagai mitra produksi dari UD. Delima Jaya. Gambar 2 menunjukkan peserta pelatihan pekerja UD. Delima Jaya dan para ibu sekitar.
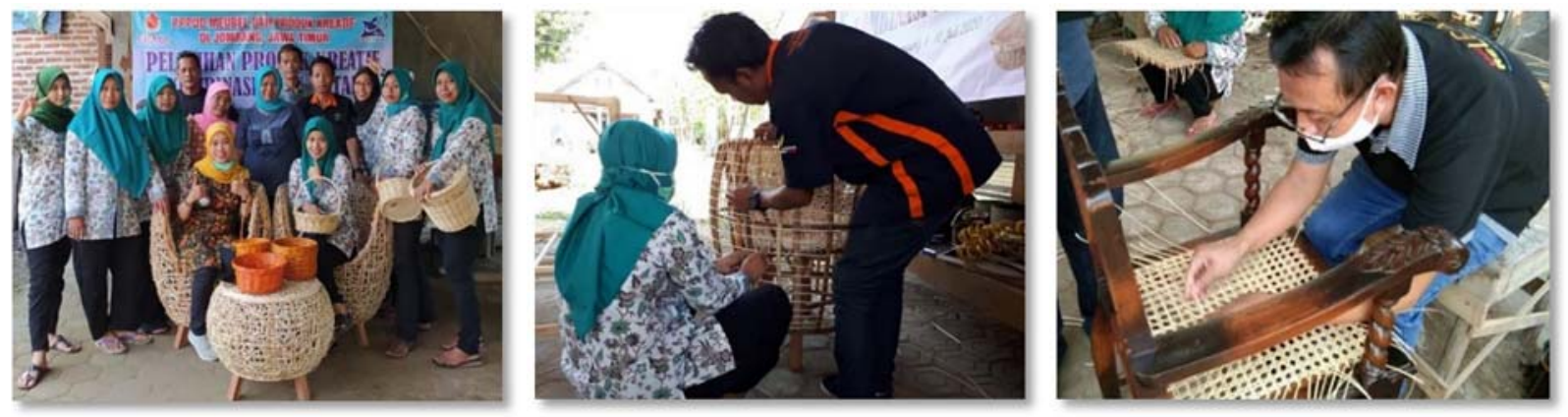

Gambar 2. Peserta dan situasi pelaksanaan pelatihan

\section{Aspek C: Kemampuan Internal}

\section{Aktivitas 5: Meningkatkan kemampuan teknologi dalam produksi}

Peningkatan kemampuan internal dalam produksi dan perlibatan mitra masyarakat untuk produksi dilaksanakan melalui pelatihan pembuatan produk kreatif kombinasi kayu dan rotan. Meskipun tujuannya adalah produk kombinasi kayu rotan, pelatihan berfokus pada teknik membuat produk dari rotan, karena dengan sendirinya produk kombinasi kayu dan rotan nantinya akan bisa diwujudkan. Pelatihan dilaksanakan selama 5 hari kerja (1 minggu) pada Juli 2020 di lokasi IKM mitra PPPUD. Peserta pelatihan 10 orang yang terdiri dari 2 orang pekerja IKM mitra dan 8 orang ibu-ibu sekitar. Instruktur sebanyak 2 orang berasal dari Malang. Hasil pelatihan menunjukkan penguasaan keterampilan yang cepat di antara para peserta serta produk hasil pelatihan yang berkualitas. Teknologi semi manual diadakan misalkan untuk memotong atau memaku rotan. Gambar 3 menampilkan cuplikan proses pembuatan produk selama pelatihan. 

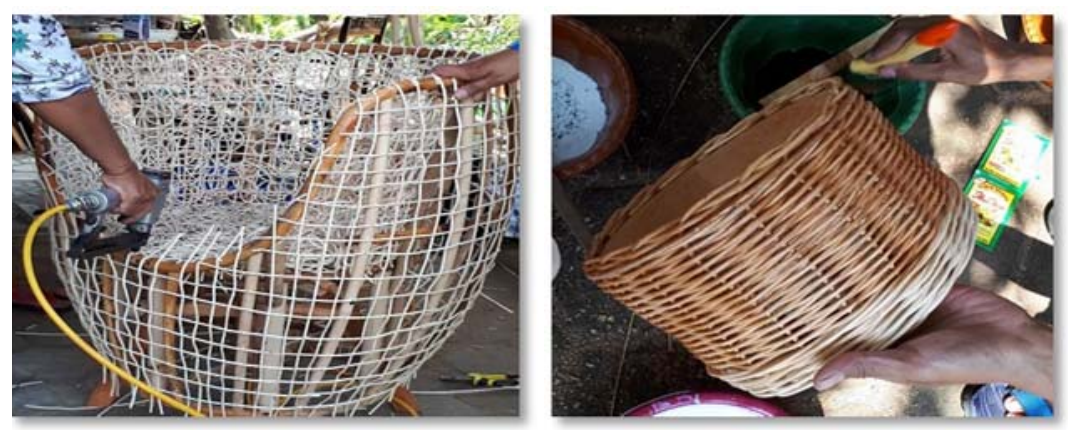

Gambar 3. Proses pembuatan produk dalam pelatihan

\section{Aktivitas 6: Memasarkan produk secara personal dan kreatif}

IKM mitra menerapkan produksi berbasis job-order, artinya membuat produk berdasarkan pemesanan. Contoh produk hasil pelatihan yang bisa ditawarkan ditampilkan di Gambar 4. Untuk mendapatkan order, upaya pemasaran diperlukan. Dalam job-order upaya pemasaran melalui personal selling, meskipun dianggap cara konvensional, lebih berdaya guna dibandingkan dengan media online. Media komunikasi online diperlukan dalam mendukung personal selling.
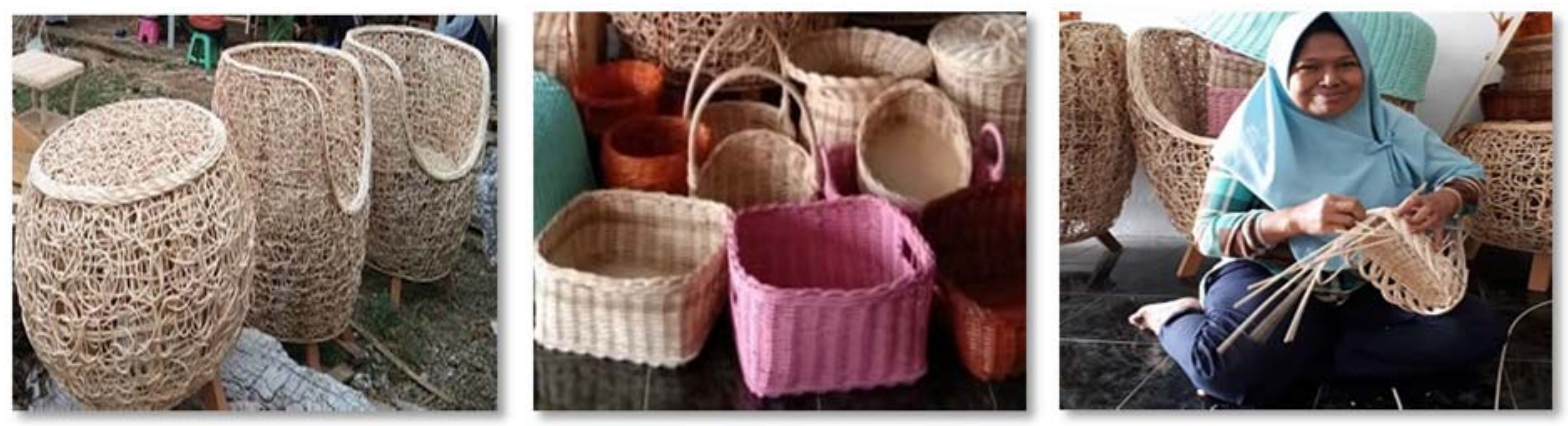

Gambar 4. Contoh produk anyaman rotan dan ibu mitra kerja

\section{Relevansi dan Manfaat bagi Mitra IKM}

Bagi IKM mitra PPPUD ini, pelatihan ini telah memberikan keterampilan baru dan sekaligus membuka satu jenis produk baru yaitu produk anyaman rotan. Beberapa pesanan telah dipenuhi. Produk anyaman rotan tersebut sebenarnya bukanlah produk akhir yang dituju, karena tujuannya ialah produk mebel kombinasi kayu dan rotan, yang berbasis pada kompetensi IKM ini di bidang mebel kayu. Keterampilan yang diperoleh mudah digunakan pada pembuatan produk mebel kombinasi kayu rotan, karena menggunakan teknik anyam rotan yang sama.

\section{Relevansi dan Manfaat bagi Masyarakat Peserta}

Sejumlah delapan orang ibu sekitar telah meningkatkan keterampilan untuk membuat produk rotan. Didalam pelatihan mereka dengan cukup cepat menguasai teknik anyam dan membuat produk. 
ABDIMAS: Jurnal Pengabdian Masyarakat Universitas Merdeka Malang

Volume 6, No. 1, February 2021: 90-98

Mereka bisa menggunakan keterampilannya untuk kegiatan produksi sendiri, atau bermitra dengan IKM mitra PPPUD ini. Keberlanjutan kegiatan pelatihan ditunjukkan salah satunya dengan keterlibatan ibu-ibu yang mendapat pelatihan, telah menjadi mitra kerja dalam waktu luangnya. Foto paling kanan dari Gambar 4 di atas diambil 5 minggu setelah pelatihan, yang menunjukkan bahwa ketika IKM mitra mendapatkan pesanan, maka ibu-ibu mengerjakannya di waktu luang.

\section{Relevansi bagi Pelaksanaan Program PPPUD}

Pelaksanaan kegiatan pelatihan ini menjadi suatu solusi penting bagi berlangsungnya pelaksanaan PPPUD ini, yang terhenti dengan adanya pembatasan sosial berskala besar pandemi COVID-19. Penggunaan instruktur praktisi yang dipilih oleh UKM mitra, sangat efektif karena pengalaman praktisnya.

\section{Faktor Pendukung dan Penghambat}

Faktor yang mendukung keberhasilan kegiatan pelatihan pada UKM mitra PPPUD dengan melibatkan masyarakat dan mitra bisnis (instruktur) ialah kesadaran dan pemahaman dari mitra UKM bahwa melibatkan masyarakat sekitar untuk bisa maju bersama sebagai kesatuan perspektif bisnis dan sosial. Hal ini sejalan dengan arahan program pengabdian masyarakat dari Kemenristek/BRIN untuk memberikan kemanfaatan yang besar dan luas dari penggunaan dana APBN.

Faktor penghambat dalam pelaksanaan kegiatan ini, secara umum, adalah kondisi pandemi COVID-19, dimana para peserta tidak bisa bebas berdekatan dengan peserta lain. Demikian juga tim pelaksanan hanya hadir terbatas pada salah satu hari dari 5 hari kegiatan pelatihan.

\section{SIMPULAN DAN SARAN}

\section{Simpulan}

Program pemberdayaan masyarakat melalui Program Pengembangan Produk Unggulan Daerah (PPPUD) ini, dengan salah satu kegiatannya, telah berhasil meningkatkan kemampuan sumber daya manusia dari IKM mitra. Kesimpulan kegiatan ini menunjukkan prinsip 3 elemen di atas untuk menangkap kebutuhan pasar yang dinamis untuk produk kreatif, serta kemitraan dengan para pelaku dalam rantai pasok produk kreatif tersebut, dan peningkatan kemampuan internal secara dinamis dengan adaptasi yang terus menerus. Pelatihan bagi IKM mitra PPPUD dan masyarakat sekitar ini bisa dipandang sebagai langkah awal. Pengembangan desain produk kreatif dengan kombinasi kayu dan rotan seperti yang diharapkan akan bisa terwujud dengan keterampilan yang diperoleh. Kemampuan kewirausahaan dari pengelola dan pemilik untuk membuat produk kreatif baru berdasarkan pada permintaan pasar serta kondisi persaingan menunjukkan penerapan orientasi pasar. Hal ini juga didapatkan dari sebuah studi pada IKM mebel di Bali yang menunjukkan adanya orientasi pasar dari para IKM dan keterkaitannya dengan internasionalisasi produk mebel (Sari \& Yasa, 2016). Tantangan yang dihadapi IKM mebel khususnya produk rotan salah satunya ialah kemiripan atau kesamaan desain produk (Rohaetin $\&$ 
Norrahmi, 2020). Hal ini menjadi pemacu terus menerus bagi setiap IKM mebel untuk mengembangkan desain produk yang kreatif.

\section{Saran}

Saran atau rekomendasi ditujukan kepada para pelaksana program pengabdian masyarakat yang melaksanakan kegiatan pelatihan bagi mitra UKM. Terkadang pelaksana program berpikir bahwa tahu tentang 3 hal berikut: (1) Pelaksana tahu akan kebutuhan mitra terhadap keterampilan atau materi tertentu; (2) Pelaksana tahu instruktur yang tepat; dan (3) Pelaksana tahu mekanisme pelaksanaan pelatihan. Saran yang diberikan ialah untuk lebih memberikan kebebasan pada mitra IKM untuk menetapkan keterampilan yang mau ditingkatkan, instruktur, dan metode atau lama pelatihan. Hal ini akan meningkatkan efektivitas program pelatihan.

\section{Ucapan Terima Kasih}

Terima kasih kepada Kemenristek/BRIN atas hibah PPPUD tahun 2020, serta Flipmas Legowo Jawa Timur yang telah memfasilitasi pertemuan dengan Pemda Kabupaten Jombang di saat proses pengajuan proposal.

\section{DAFTAR PUSTAKA}

Handayani, N. U., Ihsani, A., \& Suliantoro, H. (2016). Penilaian kinerja klaster industri pada sentra mebel di Desa Tahunan Jepara. Seminar Nasional IENACO, 525-532.

Handayani, N. U., Santoso, H., \& Pratama, A. I. (2012). Faktor-faktor yang memengaruhi peningkatan daya saing klaster mebel di Kabupaten Jepara. Jurnal Teknik Industri, 13(1), 2230.

https://doi.org/10.22219/jtiumm.vol13.no1.22-30

Iskandar, I., Putri, Y. A., Sani, M., Hamidah, S., \& Irawan, R. (2018). Kinerja pemasaran pada UKM mebel di Kabupaten Kuningan. Jurnal Equilibrium, 15(januari-Juni), 64-74.

https://doi.org/10.1017/CBO9781107415324.004

Kusumawardhani, A., \& Mccarthy, G. (2013). Innovation in small and medium-sized wood-furniture firms in Central Java, Indonesia. Proceedings of the International Conference on Managing the Asian Century, 471-480. https://doi.org/https://doi.org/10.1007/978-981-4560-61-0_53

Muslikah, N. A., Haryono, A. T., \& Harini, C. (2018). Pengaruh kompetensi entrepreneurial, strategi kewirausahaan dan modal sosial terhadap keunggulan kompetitif berkelanjutan dengan kinerja usaha (pengusaha) sebagai variabel intervening (Studi kasus UKM mebel di Desa Kembang Kab. Jepara). Journal of Management, 4(4), 1-20.

Nurlaela, S., Hadi, S., Shodiq, M. F., \& Hadi, P. (2014). Ipteks product for export industry wood crafts furniture in the District Klaten Central Java, Indonesia. Review of Integrative Business \& Economics Research, 4(1), 350-356.

Nurrochmat, D. N., Yovi, E. Y., Hadiyati, O., Sidiq, M., \& Erbaugh, J. T. (2015). Changing policies over timber supply and its potential impacts to the furniture industries of Jepara, Indonesia. Jurnal 
ABDIMAS: Jurnal Pengabdian Masyarakat Universitas Merdeka Malang

Volume 6, No. 1, February 2021: 90-98

Manajemen Hutan Tropika (Journal of Tropical Forest Management), 21(1), 36-44.

https://doi.org/10.7226/jtfm.21.1.36

Pratono, A. H. (2019). Cross-cultural collaboration for inclusive global value chain: A case study of rattan industry. International Journal of Emerging Markets, 15(1), 149-170.

https://doi.org/10.1108/IJOEM-01-2017-0028

Rohaetin, S., \& Norrahmi, I. (2020). Analisis penerapan manajemen operasional (desain produk dan rantai pasokan) pada UKM rotan Kelompok Pahari Palangkaraya. Equilibrium, 8(2), 155-165.

Sari, N. N. M. P., \& Yasa, N. N. K. (2016). Peran keunggulan kompetitif memediasi orientasi pasar dengan internasionalisasi UKM mebel Kabupaten Badung. E-Jurnal Ekonomi Dan Bisnis Universitas Udayana, 5(6), 1651-1678. 